University of Nebraska - Lincoln

DigitalCommons@University of Nebraska - Lincoln

Faculty Publications, UNL Libraries

Libraries at University of Nebraska-Lincoln

$5-28-2008$

\title{
A Typology of Librarian Status at Land Grant Universities
}

Mary K. Bolin

University of Nebraska--Lincoln, mbolin2@unl.edu

Follow this and additional works at: https://digitalcommons.unl.edu/libraryscience

Part of the Library and Information Science Commons

Bolin, Mary K., "A Typology of Librarian Status at Land Grant Universities" (2008). Faculty Publications, UNL Libraries. 156.

https://digitalcommons.unl.edu/libraryscience/156

This Article is brought to you for free and open access by the Libraries at University of Nebraska-Lincoln at DigitalCommons@University of Nebraska - Lincoln. It has been accepted for inclusion in Faculty Publications, UNL Libraries by an authorized administrator of DigitalCommons@University of Nebraska - Lincoln. 
Provided for non-commercial research and education use. Not for reproduction, distribution or commercial use.

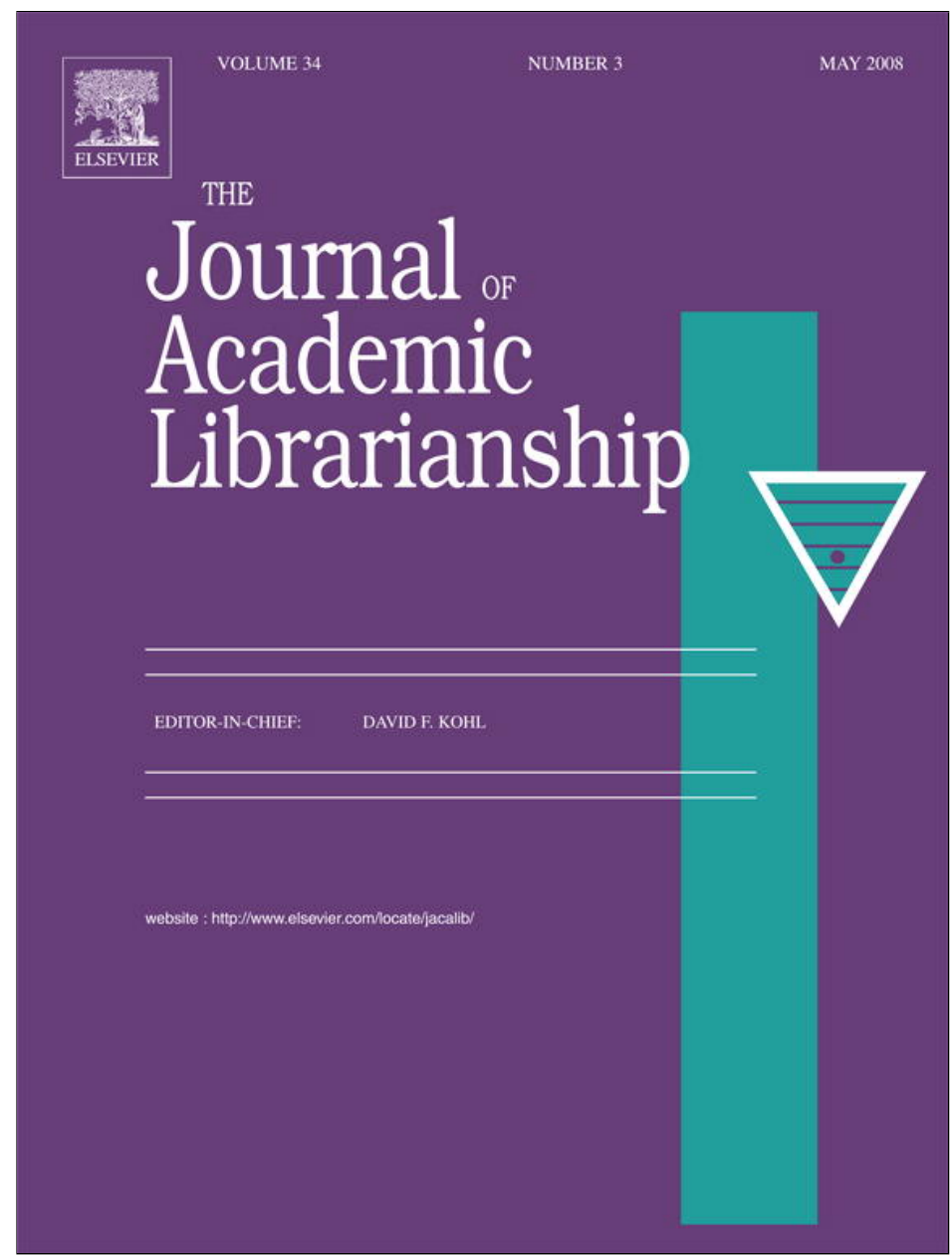

This article appeared in a journal published by Elsevier. The attached copy is furnished to the author for internal non-commercial research and education use, including for instruction at the authors institution and sharing with colleagues.

Other uses, including reproduction and distribution, or selling or licensing copies, or posting to personal, institutional or third party websites are prohibited.

In most cases authors are permitted to post their version of the article (e.g. in Word or Tex form) to their personal website or institutional repository. Authors requiring further information regarding Elsevier's archiving and manuscript policies are encouraged to visit:

http://www.elsevier.com/copyright 


\title{
A Typology of Librarian Status at Land Grant Universities
}

\author{
by Mary K. Bolin \\ Available online 10 April 2008
}

Data were gathered on librarian status at fifty land grant universities. The findings reveal four status types: Professorial, Other ranks with tenure, Other ranks without tenure, and Academic or Professional Staff. Eighty percent of institutions have librarians who are faculty and 85 percent of those are tenure-track.
Mary K. Bolin is Professor and Chair, Technical Services, University Libraries, University of Nebraska-Lincoln, Lincoln, NE 68588-4100, USA <mbolin2@unl.edu>.

\section{INTRODUCTION}

Librarians at colleges and universities have sought a role and recognition that is based on their expertise and qualifications and on their participation in the teaching and research missions of the institution. Academic librarians frequently have faculty status. The nature and desirability of faculty status is still a question for debate in some circles, for reasons that include the idea that librarianship is a profession that needs no validation from the outside; the belief that the work of librarians is not the same and not even similar to that of teaching faculty; and the notion that faculty obligations such as research and publication are unreasonable and onerous for librarians.

Although faculty status for academic librarians is longstanding and widespread, its implementation is not uniform. While appointment, assignment, and workload for teaching faculty at similar kinds of institutions fall into predictable patterns, the environment for librarians is not so uniform. A candidate for a faculty vacancy in an academic library cannot assume that "faculty" implies rank, tenure, participation in governance, a publication requirement, and so on. It might have any, all, or none of these things and still be a "faculty" position. Conversely, it might have all of them in some form, and be a staff position.

\section{Purpose of the Study}

This study is a description and categorization of librarian status at American land grant universities using data gathered from the institutional Web sites of the 1862 land grant institution in each state. Land grant universities share a number of fundamental characteristics: they are state universities (with the exception of Cornell University, the only private land grant) that share the tripartite land grant mission: teaching, research, and service. At the same time, they have geographic and cultural diversity, representing each of the fifty states in the US. Moreover, they vary widely in size. Choosing one institution in each state creates a manageable number and a coherent group of institutions.

University Web sites are the source of data on the status of librarians, including rank system, tenure status, and representation in faculty governance. The data are used to create a typology of librarian status at land grant universities $(n=50)$. This approach is an attempt to look beyond binary categorizations (faculty/staff) by examining particular characteristics of the implementation of models of status. It attempts to move beyond the atomization of describing characteristics in isolation from each other, e.g., looking at tenure, representation in 
governance, etc., without considering how those characteristics relate to each other or co-occur.

\section{Literature ReVIEW}

The literature on faculty status, academic librarians, and administrative and organizational aspects of academic libraries is voluminous. This review concentrates on the historical context of faculty status for librarians, surveys of librarian status, and arguments for and against faculty status, but it is not a comprehensive review of the literature in any of those areas.

Academic librarians have always had a close relationship with teaching faculty and their programs of research and instruction, and there have been discussions of librarian role and status throughout the profession's history, for example, Frank A. Lundy, ${ }^{1}$ Lawrence S. Thompson, ${ }^{2}$ and Arthur M. McAnally. ${ }^{3}$ Discussions such as those, and others from the early and mid-1960s, including J. Forgotson, ${ }^{4}$ J. F. Harvey, ${ }^{5}$ David C. Weber, ${ }^{6}$ Faye M. Blake, ${ }^{7}$ and Robert B. Downs, ${ }^{8}$ explore the issues of librarians' education, responsibilities, and professional identities. This discussion came to a head in the late 1960 s, when significant social changes and their effect on higher education gave academic librarians the impetus to push harder for more recognition and respect, as discussed by Judith A. Segal. ${ }^{9}$ R. Dean Galloway ${ }^{10}$ looks at progress ten years after "the rebellion that broke out at the Atlantic City [American Library Association (ALA)] conference in 1969," which "fundamentally changed the American Library Association and academic librarianship as well." The rebellion included the demand for faculty status for librarians, and ALA and its academic division, the Association of College and Research Libraries (ACRL) gave their support at that conference, resulting in the publication of the "Joint Statement" (with the American Association of University Professors [AAUP] and the Association of American Colleges [AAC]) on faculty status that first appeared in 1971. Galloway estimates that " 75 percent of ... academic libraries had faculty status in 1976 compared with 51 percent in 1966," but he remarks on "the difficulties of making comparisons of this type" due to "the subtleties of the definitions and descriptions of faculty status." ${ }^{12}$ He also notes that from 1969 to 1979, academic librarians became better educated and more qualified, and that the increase in research and publication activity caused the number of professional journals in the field to mushroom. In the early 1970s, ACRL issued a series of statements and guidelines, aimed at standardizing and codifying what was meant by faculty status. ${ }^{13-15}$ These documents include model appointment, promotion, and tenure criteria, as well as the "ACRL Standards for Faculty Status for College and University Librarians," 16 which describes nine standards to be met, including peer review for promotion, eligibility for tenure, access to sabbatical leaves and research funds, representation in governance, and so on.

One argument against faculty status asserts that librarians are not prepared to take on the scholarly responsibilities that are part of a faculty role, both because they are not prepared by their education, and because their other responsibilities are too demanding to allow it. Authors taking this position include Richard M. Dougherty, ${ }^{17} \mathrm{H}$. William Axford, ${ }^{18}$ Rachel Applegate, ${ }^{19}$ Herbert S. White, ${ }^{20}$ and Blaise Cronin, ${ }^{21}$ among many others. Mary Biggs ${ }^{22}$ advises abandoning the quest for faculty status and demanding recognition for the unique skills of the profession. Counterarguments include evidence of librarians' eagerness to embrace scholarly responsibilities, such as R. Dean Galloway ${ }^{23}$ and E. J. Josey, ${ }^{24}$ the assertion that academic librarians have no choice but to be part of scholarly culture and activity, e.g., Beverly Toy ${ }^{25}$ and Eli M. Oboler, ${ }^{26}$ and, more recently, the idea that librarians, like faculty in other fields, can make the best scholarly contribution by being true to the particular values, practices, and expertise of their field, including Janet Swan Hill. ${ }^{27,28}$

Martin Joachim ${ }^{29}$ looks at the origins of the issue and its development up until the time he was writing, nearly forty years ago. As academic libraries grew larger, there was a growing recognition of the professional and scholarly expertise of librarians. Arthur M. McAnally traces the roots of faculty status from twentyfive years previously. He describes how academic librarians "have tended more and more to apply to themselves the truly academic criteria which the classroom faculty apply to themselves." 30

Writing again a few years later, Arthur M. McAnally ${ }^{31}$ observes that the profession was held back from achieving faculty status in the early twentieth century by "housekeeping" (librarians engaging in menial tasks rather than assuming professional responsibility) and the low quality of library education. He lists a number of other factors, including the large numbers of librarians who are women, the autocratic nature of many library directors, the negative views of librarians held by "classroom faculty," the lack of support from ALA, and the sincere belief that librarians should stand apart ("on their own") from other groups. He traces "the path to the present," beginning with the post-war information explosion, which required increased expertise among librarians.

Janet Swan Hill has written persuasively of the need to "wear our own clothes,"32 as faculty. She describes the characteristics of librarianship and the need to communicate them to administrators and teaching faculty. ${ }^{33}$ Hill amplifies these themes further, asserting that maintaining a faculty status system for librarians requires "constant vigilance" with regard to their status, because the story may need to be told to every new provost and various teaching colleagues. ${ }^{34}$

Judith A. Segal ${ }^{35}$ describes the efforts of the Library Association of the City Colleges of New York (LACCNY) to obtain faculty status. The group spent the years from 1939 to 1965 attempting to achieve their goal. Segal ascribes their failure to political and academic naïveté, and their eventual victory to the social and educational climate of the 1960s and a higher education political environment in which change was easier to achieve.

The literature of librarianship has many opinion pieces on the topic of faculty status, e.g., Dougherty, ${ }^{36,37}$ White, ${ }^{38,39}$ Catherine Murray-Rust, ${ }^{40}$ Deborah A. Carver, ${ }^{41}$ and a number of studies that present and analyze the arguments for and against, including Mark Y. Herring and Michael Gorman, ${ }^{42}$ Fred Hill and Robert Hauptmann, ${ }^{43}$ Janet Swan Hill, ${ }^{44}$ Donald E. Riggs, ${ }^{45}$ Louise S. Sherby, ${ }^{46}$ Norman E. Tanis, ${ }^{47}$ and Beth J. Shapiro. ${ }^{48}$ Diane E. Ruess $^{49}$ argues for more choice in librarian appointments, while Philip J. Jones and James Stivers ${ }^{50}$ find the separation between librarians and other library employees counter-productive.

Deborah O. Lee ${ }^{51}$ investigates the impact of tenure on librarians' starting salaries, finding that there is no particular benefit. Elizabeth C. Henry and Dana M. Caudle ${ }^{52}$ studied the effect of tenure on turnover in academic libraries. They found that tenure had little effect on turnover in the institutions surveyed. Pamela $\mathrm{S}$. Bradigan and Carol A. Mularski ${ }^{53}$ explore the evaluation of publications in the promotion and tenure process. John M. Budd $^{54}$ also considers publishing activity and analyzing patterns from academic libraries. Danielle Bodrero Hoggan ${ }^{55}$ summarizes the sometimes-contradictory advantages and disadvantages of faculty status that have been demonstrated by research. 
There is quantitative research on what institutions have faculty status for librarians, with some information on the various faculty models. Virgil F. Massman ${ }^{56}$ surveyed nineteen state colleges and universities in Michigan, Minnesota, and Wisconsin, in 1969. He surveyed both librarians and teaching faculty about librarian status. W. Bede Mitchell ${ }^{57}$ surveyed Carnegie Doctoral I and II institutions $(n=98)$. He surveyed the vice president for academic affairs and the library director, and looked at tenure rates for librarians and the implementation of the ACRL standards for faculty status. He found that librarians and teaching faculty achieved tenure at the same rate, regardless of whether librarians had a publication requirement. Academic vice presidents believed that librarian faculty status was beneficial to institutions, but that librarians did not merit it. W. Bede Mitchell and Mary Reichel ${ }^{58}$ surveyed nearly 700 libraries on the publication requirement for librarians. Librarians at 54 percent of the institutions were on tenure-track. Of that 54 percent, 60 percent required scholarship and 34 percent encouraged it. In the three-year period that was examined, 92 percent of librarians who went up for tenure were successful.

Shannon Cary ${ }^{59}$ describes an ACRL study that compiled data on librarian status and participation in governance. ${ }^{60}$ ACRL surveyed more than 800 academic libraries at all types of institutions on the nine conditions for faculty status that are specified in the ACRL standards. The results were reported for the survey overall and separated by institution type (associate, bachelor, master, and doctoral degree-granting). Associate level institutions reported the most equality between librarians and teaching faculty, whereas bachelor's institutions reported the least.

Janet Krompart and Clara DiFelice ${ }^{61}$ reviewed faculty status surveys from 1971 (when the ACRL standards were first adopted) until the mid-1980s. The thirty-six surveys examined included national surveys done by associations such as ALA and ACRL, as well as surveys of a state or region done by an association or individual. Krompart and DiFelice found a wide variation in librarian status and in the implementation of faculty status. They found that larger institutions were more likely to have a model of faculty status that met the ACRL standards.

\section{Methodology}

This study has its origins in a frustration with academic library Web sites. It began with the question, "can I find out from the library's website whether the librarians at a particular university are faculty?" In many cases, the answer was either, "no," or "not very easily," although the answer could generally be found elsewhere on the university site. Published surveys of librarian status seemed equally opaque and uninformative, although in a different way. The information is often presented free from any organizational context. While that data are useful, there are still questions about what it really means. Discussions and surveys of faculty status often express it as a binary condition: faculty/ not faculty. A continuum or matrix is a richer and more revealing way of looking at it. The data elements cluster together to create types of status. Some elements (e.g., tenure) are more salient, and have more weight in creating the typology, but all the elements are significant aspects of status.

\section{Research Design}

The methodology is a variation of the survey method. The population is small enough that sampling was not necessary. Rather than creating a questionnaire and asking libraries to self-report this data, it was sought on Web sites that provide information about the institution. With each of the questions, the number of possible answers was not predetermined, i.e., there could have been any number of possible administrator titles or rank systems. Data gathered:

- University employee group (faculty or staff)

- Title of library administrator (dean, director, etc.)

\begin{tabular}{lcc}
\hline \multicolumn{2}{c}{ Table 1 } & \\
& Summary of Frequencies & \\
\hline Status type & Prequency & Percent \\
1: Professorial & 21 & \\
2: Other ranks with tenure & 14 & 28 \\
3: Other ranks without tenure & 5 & 10 \\
4: Non-faculty (Staff) & 10 & 20 \\
Total & 50 & 100
\end{tabular}

Employee group

Faculty 40

Staff

Total

Administrator title

Dean

30

60

Director

University Librarian

Other

Total

Rank system

Professorial

Parallel

Librarian

Other or undetermined

Total

Tenure eligibility

Yes

34

68

No

Staff with continuing appointment

Faculty senate representation

\begin{tabular}{lrr} 
Yes & 43 & 86 \\
No & 7 & 14 \\
Total & 50 & 100 \\
\hline
\end{tabular}


- Rank system

Professorial ranks (Assistant Professor, Associate Professor, Professor)

O Parallel ranks (Assistant Librarian, Associate Librarian, Librarian)

$\bigcirc$ Librarian ranks (Librarian I, II, III, IV)

Other

- Tenure eligibility

- Representation on faculty senate

A summary of the typology data is found in Appendix A. The information is contained in organizational charts, appointment, promotion, and tenure documents, faculty handbooks, policy manuals, vacancy announcements, and so on, on sites maintained by the library and/or by the provost, president, senate, governing board, or Human Resources office.

\section{Procedures for Data Analysis}

The data on status were first compiled in a spreadsheet and then imported into SPSS where frequencies and cross tabulations were created. The result of that analysis was used to devise a typology, a system of status types. The typology is based on employee group, rank system, and tenure status. The typology reflects clusters of characteristics. Some combinations are common, others rare or non-existent.

\section{Results}

These frequencies are discussed later in the article (Table 1).

\section{Librarian Status Typology}

Types (Fig. 1; Table 2):

1. Professorial ranks

2. Other ranks with tenure

\begin{tabular}{lcc}
\hline \multicolumn{3}{c}{ Table 2 } \\
Frequency of Status Types \\
\hline & Frequency & Percent \\
\hline 1: Professorial & 21 & 42 \\
2: Other ranks with tenure & 14 & 28 \\
3: Other ranks without tenure & 5 & 10 \\
4: Non-faculty (Staff) & 10 & 20 \\
Total & 50 & 100 \\
\hline
\end{tabular}

3. Other ranks without tenure

4. Non-faculty (Professional or academic staff).

The rationale for the typology is that professorial rank (with tenure, although there is one institution that lacks it) is an obvious category, because it is the universal teaching faculty model. Likewise, academic or professional staff status is another obvious type, because it is the model in which librarians are not faculty at all. The typology has characteristics of both a matrix and a continuum. Seen as a continuum, there are two models between the extremes of professorial ranks and academic staff. They are "other ranks" (parallel, e.g., Assistant Librarian, and librarian, e.g., Librarian I) with tenure and other ranks without tenure. When institutions where librarians are faculty and have parallel or librarian ranks are combined, two-thirds of them have tenure. Parallel and librarian rank systems represent some degree of "equivalence" between librarians and teaching faculty, in which Librarian I or Assistant Librarian is considered the equivalent of Assistant Professor. Seen as a matrix, the typology shows that the combination "Employee Group =Faculty" and "Tenure =No" is rare. Tenure is a very significant aspect of faculty status, so it makes sense to use it in designating types of status.

Type 1 and Type 2 are the easiest to identify. Librarians who are tenure-track faculty clearly identify themselves this way in their documents. Types 3 and 4 are sometimes hard to distinguish, because of the parallel systems that have been constructed. Collective bargaining is a factor in some of these cases,

\section{Figure 1 \\ Land Grant Librarian Status Typology \\ Status Type Frequency}

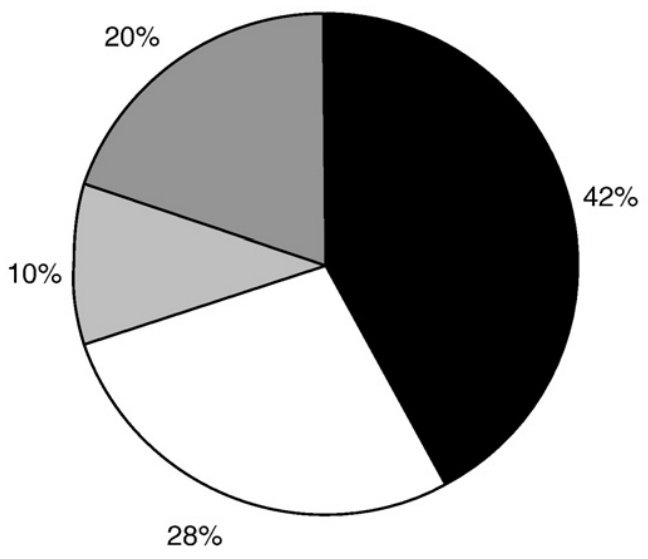

1: Professorial (42\%)

$\square$ 2: Other ranks with tenure (28\%)

3: Other ranks without tenure (10 percent)

$\square$ 4: Non-faculty (Staff) $(20 \%)$

$28 \%$ 
and its effect is not a part of this research. The parallel systems are interesting, however, in that their rationale seems to be that for librarians to "wear our own clothes,"62 some institutions have given librarians a status that mimics some aspects of faculty status, but which is called "professional librarian," or something similar, and is a recognition of the education and expertise that make one a member of the library profession. While that may be a comfortable position for some librarians, it negates one of the strong and early rationales for faculty status for librarians: that there is safety in numbers, and that librarians are better off being part of a larger group (faculty), which will help them reach their goals of recognition, appropriate salaries, and so on ${ }^{63}$. On the other hand, the librarians with parallel systems may also be part of a collective bargaining unit that includes faculty or other academic professionals.

\section{FrEQUENCIES}

The basic separation of librarian status into faculty and staff shows that four fifths of the librarians in the population have faculty status for librarians. The details of that status appear in Table 1 and are discussed below.

\section{Administrator Title}

"Dean" is the title of the head of the library in 60 percent of the population studied. "Director" and "University Librarian" account for more than 30 percent of the remaining institutions, with "Other," a category that includes titles such as "Vice Provost," with 8 percent, or four institutions. The head of a college is a dean. The title is sometimes used for the head of student services ("Dean of Students"), but is never used for any other unit that is not part of Academic Affairs. All the library administrators in this population report to the academic vice president, and nearly all are part of a "Council of Deans," even if they have another title. The University of Wyoming Library Regulations states that the library director is a dean when dealing with library faculty matters such as appointment and promotion. "Director" is often an academic title that is used for interdepartmental programs, programs or departments called "School," and units such as the Writing Program, as well as administrative units such as Athletics, Career Services, or Computing. "Director" describes an action, the administrative act of directing, and is a generic title that has no specific connotation of libraries or of academe. "University Librarian" emphasizes the professional role, and is similar to a title such as University Counsel, University Attorney, or even Bursar or Registrar.

\section{Rank System}

Faculty rank is one of ACRL's nine conditions for librarian faculty status. ${ }^{65}$ Surveys of faculty status generally seem to consider both professorial and parallel (e.g., Assistant Librarian) rank systems to be faculty rank. The professorial rank system is predominant in this population, with more than 40 percent represented. Obviously, librarians who have professorial rank are faculty. "Librarian" ranks and parallel ranks (i.e., Assistant Librarian parallels Assistant Professor) each account for a little more than one fourth of the population. Twenty percent of the libraries in the population have librarians who are staff rather than faculty. About one-third of the libraries with parallel or librarian ranks have staff librarians rather than faculty.

\section{Tenure Eligibility}

Nearly 70 percent of the libraries in the population have librarians who are tenure-track faculty. That includes institu- tions in which terms like "continuing appointment" and "permanent status" are used instead of tenure. "Continuing appointment" is also used in some university faculty handbooks as a definition or clarification of the meaning of tenure. Some librarians, both faculty and staff, e g., Wyoming (faculty) and Wisconsin (staff) have multi-year contracts, generally three to five years, instead of tenure. Four of the ten institutions in which librarians are staff have a form of continuing appointment that closely approximates tenure.

\section{Faculty Senate Representation}

The overwhelming majority of librarians in these institutions serve in the faculty senate, including some who are staff.

\section{Cross Tabulations}

The combination of frequency and cross-tabulation is the basis for the status typology. The predominance of certain characteristics (tenure-track, dean as administrator, representation in senate) in these data makes some of the cross tabulations less significant. The discussion below refers to data displayed in Table 3 .

\section{Employee Group-Administrator Title}

"Dean" and "Faculty" appear together most often, and there are only two cases in which the library is headed by a dean but the librarians are staff. The other administrator titles are more evenly split between faculty and staff librarians.

\section{Employee Group-Rank System}

Only faculty members are called "professor," so the co-occurrence of professorial rank and faculty status is not surprising. Parallel and Librarian ranks are split about two-to-one, with two-thirds of those rank groups being faculty, and one-third being staff.

\section{Employee Group-Tenure Eligibility}

A large majority of the librarians in the population who are faculty also have tenure. Among the librarians who are staff, 40 percent have a form of continuing appointment.

\section{Employee Group-Faculty Senate Representation}

Only a small number of the librarians who are faculty are not represented in the faculty senate. Fifty percent of librarians in the population who are staff are represented in the faculty senate.

\section{Administrator Title-Rank System}

The administrative title "dean" and professorial rank appear the most frequently in this data. Therefore, it is not surprising that they also appear together most often, representing one-third of the population.

\section{Administrator Title-Tenure Eligibility}

Most institutions in the population have tenure for library faculty. It is nevertheless interesting that "dean" and "university librarian" represent nearly all of the 70 percent of tenure-granting institutions, while nearly 60 percent (four out of seven) of the libraries headed by a "director" do not grant tenure to librarians.

\section{Administrator Title-Faculty Senate REPRESENTATION}

Most librarians in the population are represented in the faculty senate. "Director" once again represents a higher percentage of negatives than the other categories. 
Table 3

Summary of Cross Tabulations

Employee group-Administrator title cross tabulation

\begin{tabular}{lccccc}
\hline & Dean & Director & University Librarian & Other & Total \\
\hline Faculty & 28 & 4 & 5 & 3 \\
Staff & 2 & 4 & 3 & 1 \\
Total & 30 & 8 & 8 & 40
\end{tabular}

Employee group-Rank system cross tabulation

\begin{tabular}{|c|c|c|c|c|c|}
\hline & Professorial & Parallel & Librarian & $\begin{array}{c}\text { Other or } \\
\text { Undetermined }\end{array}$ & Total \\
\hline Faculty & 21 & 9 & 10 & 0 & 40 \\
\hline Staff & 0 & 4 & 4 & 2 & 10 \\
\hline Total & 21 & 13 & 14 & 2 & 50 \\
\hline
\end{tabular}

Employee group-Tenure eligibility cross tabulation

\begin{tabular}{lcccc}
\hline & Yes & No & $\begin{array}{c}\text { Staff with Continuing } \\
\text { Appointment }\end{array}$ & Total \\
\hline Faculty & 33 & 7 & 0 & 40 \\
Staff & 0 & 6 & 4 & 10 \\
Total & 33 & 13 & 4 & 50
\end{tabular}

Employee group-Faculty senate representation cross tabulation

\begin{tabular}{lccc}
\hline & Yes & No & Total \\
\hline Faculty & 38 & 2 & 40 \\
Staff & 5 & 5 & 10 \\
Total & 43 & 7 & 50
\end{tabular}

Administrator title-Rank system cross tabulation

\begin{tabular}{|c|c|c|c|c|c|}
\hline & Professorial & Parallel & Librarian & Other & Total \\
\hline Dean & 17 & 7 & 6 & 0 & 30 \\
\hline Director & 1 & 2 & 2 & 2 & 7 \\
\hline University Librarian & 3 & 3 & 3 & 0 & 9 \\
\hline Other & 0 & 1 & 3 & 0 & 4 \\
\hline Total & 21 & 13 & 14 & 2 & 50 \\
\hline
\end{tabular}

Administrator title-Tenure eligibility cross tabulation

\begin{tabular}{lcccc}
\hline & Yes & No & $\begin{array}{c}\text { Staff with Continuing } \\
\text { Appointment }\end{array}$ & Total \\
\hline Dean & 25 & 4 & 1 & 30 \\
Director & 2 & 4 & 1 & 7 \\
\hline
\end{tabular}


Table 3 (continued)

Administrator title-Tenure eligibility cross tabulation

\begin{tabular}{lcccc}
\hline & Yes & No & $\begin{array}{c}\text { Staff with Continuing } \\
\text { Appointment }\end{array}$ & Total \\
\hline University Librarian & 5 & 2 & 2 & 9 \\
Other & 1 & 2 & 0 & 4 \\
Total & 34 & 12 & 4 & 50
\end{tabular}

Administrator title-Faculty senate representation cross tabulation

\begin{tabular}{lccc}
\hline & Yes & No & Total \\
\hline Dean & 29 & 1 & 30 \\
Director & 4 & 3 & 7 \\
University Librarian & 7 & 2 & 9 \\
Other & 3 & 1 & 4 \\
Total & 43 & 7 & 50
\end{tabular}

Rank system-Tenure eligibility cross tabulation

\begin{tabular}{lcccc}
\hline & Yes & No & $\begin{array}{c}\text { Staff with Continuing } \\
\text { Appointment }\end{array}$ & Total \\
\hline Professorial & 20 & 1 & 0 & 21 \\
Parallel & 6 & 4 & 3 & 13 \\
Librarian & 7 & 6 & 0 & 14 \\
Other & 0 & 1 & 1 & 2 \\
Total & 33 & 12 & 4 & 50
\end{tabular}

Rank System-Faculty senate representation cross tabulation

\begin{tabular}{lccc}
\hline & Yes & No & Total \\
\hline Professorial & 21 & 0 & 20 \\
Parallel & 11 & 2 & 13 \\
Librarian & 11 & 3 & 15 \\
Other & 0 & 2 & 2 \\
Total & 43 & 7 & 50
\end{tabular}

Tenure eligibility-Faculty senate representation cross tabulation

\begin{tabular}{lccc}
\hline & Yes & No & Total \\
\hline Yes & 33 & 0 & 33 \\
No & 8 & 5 & 13 \\
Staff with Continuing Appointment & 2 & 2 & 4 \\
Total & 43 & 7 & 50 \\
\hline
\end{tabular}




\section{Rank System-Tenure Eligibility}

The co-occurrence of professorial ranks and tenure is almost without exception. Librarian ranks are almost evenly split, while parallel ranks have tenure in a majority of cases. In two of the institutions where librarians are staff with continuing appointment, they have parallel ranks, and in the other they have librarian ranks.

\section{Rank System-Faculty Senate Representation}

Since most institutions have librarians in the faculty senate, these results are not particularly interesting. In all rank systems where all or most librarians are faculty, they are overwhelmingly represented in the faculty senate.

\section{Tenure Eligibility-Faculty Senate Representation}

Tenure and senate representation have a 100 percent overlap, and even librarians without tenure serve on the senate more than 60 percent of the time.

Creating the status typology was an iterative process, in which there were repeated passes through the data and continuous updating and change. In a number of institutions, the librarians were initially identified as faculty. As the data were analyzed, it became clear that they were actually staff. Drawing the line between faculty and staff is not as easy as it would appear. Librarians with professorial rank and tenure are easily identified as faculty. In other cases, they may have ranks such as Librarian I, II, III, or Assistant and Associate Librarian, but their documents explicitly and repeatedly refer to them as faculty. There are cases, however, in which librarians have many of the characteristics of faculty, including a form of tenure ("continuing appointment," for example); are represented in the senate; have responsibilities for teaching, research, and service; but are, in fact, staff. The University of California System is an excellent example of this. Librarians in that system have a status that parallels faculty in nearly every way, but they are staff. ${ }^{66}$ In other cases, such as the University of Georgia, librarians have almost none of the characteristics of faculty, but they are faculty, and refer to themselves this way. ${ }^{67}$

\section{Conclusions, Recommendations, and Suggestions for Future Research}

Eighty percent of librarians at land grant universities are faculty members, and 85 percent of those who are faculty (thirty-four out of forty) are on tenure-track, which is 68 percent of the population. A clear and unambiguous model of faculty status is predominant in the population. In the 20 percent of libraries where the librarians are staff, there is frequently a model of governance that parallels faculty status in a number of ways, sometimes making it difficult to determine which category librarians belong to. Land grant universities have a more frequent occurrence of tenure-track faculty status for librarians than other types of institutions. The 1999 ACRL survey on faculty status among academic librarians ${ }^{68}$ does not directly address the question of "employee group," i.e., faculty or staff, but in assessing the implementation of ACRL's nine conditions for librarian faculty status, does provide some data for comparison. Among doctoral-granting universities $(n=271)$, which include all the land grant universities in the population studied, 46 percent have librarians who are on tenure-track, 53 percent have a governance structure similar to collegial faculty governance, and 45.6 percent have a peer review system for promotion. (The numbers for all Carnegie classes of institutions together $[n=976]$ are similar to those for doctoral-granting institutions.) Those three things by themselves are not necessarily indicators of faculty status, but, taken together, may give some indication. "Tenure" is limited to faculty, but it is not clear if this data element includes only tenure, or also includes the continuing appointment systems that some institutions provide for librarians who are academic staff (e.g., California). In any case, if an estimated 45 percent to 50 percent of librarians at all the doctoral-granting universities surveyed by ACRL are tenure-track faculty, that number is distinctly lower than the 68 percent who have that status at land grant universities.

\section{"Eighty percent of librarians at land grant universities are faculty members, and 85 percent of those who are faculty (thirty-four out of forty) are on tenure-track, which is 68 percent of the population."}

Although faculty status is pervasive, well defined, and well established, there is also a clear typology of status in the population. The types are based on employee group, rank, and tenure status. The largest segment is Type 1, Professorial rank faculty, with tenure (in all but one case), with twenty-one libraries. Type 2 is tenure-track faculty with other rank systems (parallel ranks, e.g., Assistant Librarian, and librarian ranks, e.g., Librarian I, II, and III) with tenure, and is next in size, with fourteen, and Type 4, academic or professional staff (nonfaculty), is next, with ten. Type 3 (non-tenure-track faculty with non-professorial ranks) is the smallest group, with five.

Librarians at land grant universities have by and large achieved the goals that academic librarians articulated forty or more years ago. A strong model of faculty status is pervasive in that population, and the librarians who are not faculty also generally have a status that recognizes their expertise and their role in the university's teaching, research, and service missions, which often is nearly indistinguishable from faculty status.

An obvious area for further research is to extend the status typology to other populations. Those populations may overlap with land grants, and include ARL institutions, state universities, Carnegie classification categories such as doctoralgranting, and so on. Applying the typology to those populations would undoubtedly provide contrasting proportions of each status type, and it might also change the typology itself, depending on the characteristics of the populations. Looking at size as a factor in status might also yield interesting results, as would a consideration of the collective bargaining environment.

The status typology that is described here is the result of framing the research questions in a particular way. The result is only one of many typologies or other ways of analyzing that could be developed to look at librarian status. Further research is needed to investigate the question of status in other ways. Other answers will come from other questions, and many different questions can be asked about the status of academic librarians. 
Appendix A

Typology Data

\begin{tabular}{|c|c|c|c|c|c|}
\hline Library & Administrator & Rank & Tenure & Senate & Type \\
\hline Arizona State University & Dean & Staff, Parallel ranks & $\begin{array}{l}\text { Continuing } \\
\text { appointment }\end{array}$ & Yes & 4 \\
\hline Auburn University & Dean & Librarian & Yes & Yes & 2 \\
\hline Clemson University & Dean & Parallel & Yes & Yes & 2 \\
\hline Colorado State & Dean & Professorial & Yes & Yes & 1 \\
\hline Cornell University & University Librarian & Staff, Parallel ranks & No & No & 4 \\
\hline Iowa State University & Dean & Professorial & Yes & Yes & 1 \\
\hline Kansas State University & Dean & Professorial & Yes & Yes & 1 \\
\hline Louisiana State University & Dean & Parallel & Yes & Yes & 2 \\
\hline Michigan State University & Vice Provost & Librarian & Yes & Yes & 2 \\
\hline Mississippi State University & Dean & Professorial & Yes & Yes & 1 \\
\hline Montana State University & Dean & Professorial & Yes & Yes & 1 \\
\hline New Mexico State University & Dean & Professorial & Yes & Yes & 1 \\
\hline North Carolina State University & $\begin{array}{l}\text { Associate } \\
\text { Vice Provost }\end{array}$ & Librarian & No & No & 3 \\
\hline North Dakota State University & Director & Staff, unknown ranks & No & No & 4 \\
\hline Ohio State University & Director & Professorial & Yes & Yes & 1 \\
\hline Oklahoma State University & Dean & Professorial & Yes & Yes & 1 \\
\hline Oregon State University & University Librarian & Professorial & Yes & Yes & 1 \\
\hline Pennsylvania State University & Dean & Parallel & Yes & Yes & 2 \\
\hline Purdue University & Dean & Professorial & Yes & Yes & 1 \\
\hline Rutgers University & University Librarian & Librarian & Yes & Yes & 2 \\
\hline South Dakota State University & Dean & Professorial & Yes & Yes & 1 \\
\hline Texas A\&M University & Dean & Professorial & Yes & Yes & 1 \\
\hline University of Alaska, Fairbanks & Dean & Professorial & Yes & Yes & 1 \\
\hline University of Arkansas & Dean & Parallel & Yes & Yes & 2 \\
\hline University of California & University Librarian & Staff, Parallel ranks & Career status & No & 4 \\
\hline University of Connecticut & Vice Provost & Staff, Librarian ranks & No & Yes & 4 \\
\hline University of Delaware & Director & Parallel & No & Yes & 3 \\
\hline University of Florida & Director & Parallel & Yes & Yes & 2 \\
\hline University of Georgia & University Librarian & Librarian & No & No & 3 \\
\hline University of Hawaii at Manoa & University Librarian & Librarian & Yes & Yes & 2 \\
\hline University of Idaho & Dean & Professorial & Yes & Yes & 1 \\
\hline $\begin{array}{c}\text { University of Illinois at } \\
\text { Urbana-Champaign }\end{array}$ & University Librarian & Professorial & Yes & Yes & 1 \\
\hline University of Kentucky & Dean & Librarian & Yes & Yes & 2 \\
\hline University of Maine & Dean & Staff & No & No & 4 \\
\hline University of Maryland & Dean & Librarian & Yes & Yes & 2 \\
\hline University of Massachusetts- Amherst & Director & Staff, Librarian ranks & No & Yes & 4 \\
\hline University of Minnesota & University Librarian & Staff, Librarian ranks & $\begin{array}{l}\text { Continuing } \\
\text { appointment }\end{array}$ & Yes & 4 \\
\hline University of Missouri-Columbia & Director & Staff, Librarian ranks & No & Yes & 4 \\
\hline
\end{tabular}


ApPendix A (continued)

\begin{tabular}{|c|c|c|c|c|c|}
\hline Library & Administrator & Rank & Tenure & Senate & Type \\
\hline University of Nebraska-Lincoln & Dean & Professorial & Yes & Yes & 1 \\
\hline University of Nevada, Reno & Dean & Librarian & Yes & Yes & 2 \\
\hline University of New Hampshire & University Librarian & Professorial & Yes & Yes & 1 \\
\hline University of Rhode Island & Dean & Professorial & Yes & Yes & 1 \\
\hline University of Tennessee & Dean & Professorial & Yes & Yes & 1 \\
\hline University of Vermont & Dean & Professorial & No & Yes & 1 \\
\hline University of Wisconsin-Madison & Director & Staff, Other ranks & $\begin{array}{l}\text { Indefinite } \\
\text { appointment }\end{array}$ & No & 4 \\
\hline University of Wyoming & Dean & Parallel & No & Yes & 3 \\
\hline Utah State University & Vice Provost & Parallel & Yes & Yes & 2 \\
\hline Virginia Tech University & Dean & Professorial & Yes & Yes & 1 \\
\hline Washington State University & Dean & Librarian & Yes & Yes & 2 \\
\hline West Virginia University & Dean & Parallel & No & Yes & 3 \\
\hline
\end{tabular}

\section{Notes AND REFERENCES}

1. Frank A. Lundy, "Faculty Rank of Professional Librarians," College \& Research Libraries 12 (1951): 113.

2. Lawrence S. Thompson, "Preparation and Status of Library Personnel," Library Trends 1 (1952): 95-104.

3. Arthur M. McAnally, "The Dynamics of Securing Academic Status," College and Research Libraries 18 (1957): 386-395.

4. J. Forgotson, "A Staff Librarian Views the Problem of Status," College \& Research Libraries 22 (July 1961): 275-281.

5. J.F. Harvey, "Advancement in the Profession," Wilson Library Bulletin 36 (1961): 146.

6. David C. Weber, “Tenure' for Librarians in Academic Institutions," College \& Research Libraries 27, no. 2 (03, 1966): 99-102.

7. Fay M. Blake, "Tenure for the Academic Librarian," College \& Research Libraries 29, no. 6 (11, 1969): 502-504.

8. Robert B. Downs, "Status of Academic Librarians in Retrospect," College \& Research Libraries 29, no. 4 (07, 1968): 253-258.

9. Judith A. Segal, "Collaboration between Theory and EvidenceBased Practice-Two Cultures: Librarians and Professors," IFLA Journal 27, no. 1 (2001): 24.

10. R. Dean Galloway, "Status or Stasis: Academic Librarians 10 Years Later," American Libraries 10, no. 6 (06, 1979): 349.

11. American Library Association, Joint Statement on Faculty Status of College and University Librarians. http://www.ala.org/ala/acrl/ acrlstandards/jointstatementfaculty.htm. (accessed October 15, 2007).

12. Galloway, "Status or Stasis: Academic Librarians 10 Years Later," p. 349.

13. Association of College and Research Libraries, "ACRL Model Statement of Criteria and Procedures for Appointment, Promotion in Academic Rank, and Tenure for College and University Librarians," College \& Research Libraries News (September/ October 1973): 192-195, 243-247.

14. Association of College and Research Libraries, "ACRL Standards for Faculty Status for College and University Librarians," College \& Research Libraries News (1974, May): 112-113.

15. Association of College and Research Libraries, "ACRL Statement on the Terminal Professional Degree for Academic Librarians," American Library Association/Association of College and Research Libraries, Chicago, 1975.
16. American Library Association, Standards for Faculty Status for College and University Librarians, September 06, 2006. http:// www.ala.org/ala/acrl/acrlstandards/standardsfaculty.cfm (accessed October 15, 2007)

17. Richard M. Dougherty, "Editorial: Faculty Status: Playing on a Tilted Field," Journal of Academic Librarianship 19 (May 1993): 67.

18. H. William Axford, "The Three Faces of Eve: Or the Identity of Academic Librarianship A Symposium," Journal of Academic Librarianship 2, no. 6 (01, 1977): 276-278.

19. Rachel Applegate, "Deconstructing Faculty Status: Research and Assumptions," Journal of Academic Librarianship 19, no. 3 (July, 1993): 158.

20. Herbert S. White, "Faculty Status for Academic Librarians: The Search for the Holy Grail," Library Journal 121, no. 19 (1996): 39-40.

21. Blaise Cronin, "The Mother of all Myths," Library Journal 126, no. $3(02 / 15,2001): 144$.

22. Mary Biggs, "Sources of Tension and Conflict between Librarians and Faculty," The Journal of Higher Education 52, no. 2 (Mar.Apr., 1981): 182-201.

23. R. Dean Galloway, "The Three Faces of Axford: Or Blaming the Victim in Academia," Journal of Academic Librarianship 2, no. 6 (01, 1977): 280-281.

24. E.J. Josey, "Faculty Status in here to Stay," Journal of Academic Librarianship 2, no. 6 (01, 1977): 282-283.

25. Beverly Toy, "An Apt Summary," Journal of Academic Librarianship 2, no. 6 (01, 1977): 279-280.

26. Eli Oboler, "The Old Adam: Comments on the Three Faces of Eve," Journal of Academic Librarianship 2, no. 6 (01, 1977): $278-279$.

27. Janet Swan Hill, "Wearing our Own Clothes: Librarians as Faculty," Journal of Academic Librarianship 20, no. 2 (05, 1994): 71.

28. Janet Swan Hill, "Constant Vigilance, Babelfish, and Foot Surgery: Perspectives on Faculty Status and Tenure for Academic Librarians," portal: Libraries \& the Academy 5, no. 1 (01, 2005): $7-22$.

29. Martin Joachim, A Brief History of the Development of Faculty Status for Librarians. Prepared for the Committee on Academic Status. 1968. http://www.indiana.edu/ inula/archives/joachim.html (accessed October 15, 2007). 
30. Arthur M. McAnally, "Privileges and Obligations of Academic Status," College and Research Libraries 24 (March, 1963): $102-108$

31. Arthur M. McAnally, "Status of the University Librarian in the Academic Community," 1971. In ACRL Committee on Academic Status. Faculty Status for Academic Librarians: A History and Policy Statements. (Chicago: American Library Association, 1975), 1-30.

32. Hill, "Wearing our Own Clothes: Librarians as Faculty."

33. Hill, "Wearing our Own Clothes: Librarians as Faculty," p. 71

34. Hill, "Constant Vigilance, Babelfish, and Foot Surgery: Perspectives on Faculty Status and Tenure for Academic Librarians," p. 17

35. Segal, "Collaboration between Theory and Evidence-Based Practice-Two Cultures: Librarians and Professors."

36. Richard M. Dougherty, "Faculty Status-A Sharp Two-Edged Sword," Journal of Academic Librarianship 1 (July, 1975): 3.

37. Dougherty, "Editorial: Faculty Status: Playing on a Tilted Field."

38. White, Faculty Status for Librarians.

39. Herbert S. White, "What is a Professional in our Field?," Library Journal 123, no. 3 (02/15, 1998): 117.

40. Catherine Murray-Rust, "Should Librarians Get Tenure? Yes, It's Crucial to their Jobs," Chronicle of Higher Education 52, no. 6 (09/ 30, 2005): B10-B10.

41. Deborah A. Carver, "No, It Can Hamper their Roles," Chronicle of Higher Education 52, no. 6 (09/30, 2005): B10-B11.

42. Mark Y. Herring \& Michael Gorman, "Do Librarians with Tenure Get More Respect?" American Libraries 34, no. 6 (2003): 70.

43. Fred Hill \& Robert Hauptman, "Faculty Status for Librarians? A Response," College \& Research Libraries News 55, no. 1 (01, 1994): 26.

44. Hill, "Constant Vigilance, Babelfish, and Foot Surgery: Perspectives on Faculty Status and Tenure for Academic Librarians."

45. Donald E. Riggs, "Faculty Status for Librarians: Force-Fitting into an Inappropriate Mold or Not?" College \& Research Libraries 60 (July, 1999): 305-306.

46. Louise S. Sherby, "Academic Librarian: Librarian or Faculty Member?" Journal of Academic Librarianship 4, no. 5 (11, 1978): 379.

47. Norman E. Tanis, "A New Model for Faculty Status," Journal of Academic Librarianship 4, no. 3 (07, 1978): 137-138.

48. Beth J. Shapiro, "The Myths Surrounding Faculty Status for Librarians," College \& Research Libraries News 54, no. 10 (11, 1993): 562

49. Diane E. Ruess, "Faculty and Professional Appointment of Academic Librarians: Expanding the Options for Choice," portal: Libraries \& the Academy 4, no. 1 (01, 2004): 75-84.

50. Philip J. Jones \& James Stivers, "Good Fences Make Bad Libraries: Rethinking Binary Constructions of Employment in Academic Libraries," portal: Libraries \& the Academy 4, no. 1 (01, 2004): $85-104$
51. Deborah O. Lee, Faculty Status, Tenure, and Compensating Wage Differentials among Members of the Association of Research Libraries. (PhD diss., Mississippi State University, 2005).

52. Elizabeth C. Henry \& Dana M. Caudle, "Tenure and Turnover in Academic Libraries," College \& Research Libraries 55, no. 5 (09, 1994): 429.

53. Pamela S. Bradigan \& Carol A. Mularski, "Evaluation of Academic Librarians' Publications for Tenure and Initial Promotion," Journal of Academic Librarianship 22, no. 5 (09, 1996): 360.

54. John M. Budd, "Faculty Publishing Productivity: Comparisons Over Time," College \& Research Libraries 67, no. 3 (05, 2006): 230-239.

55. Danielle Bodrero Hoggan, "Faculty Status for Librarians in Higher Education," portal: Libraries \& the Academy 3, no. 3 (07, 2003): 431-445.

56. Virgil F. Massman, "Faculty Status for Librarians," Scarecrow Press, Metuchen, NJ, 1972.

57. W. Bede Mitchell, Faculty Status for Academic Librarians: Compliance with Standards, Opinions of University Administrators, and a Comparison of Tenure-Success Records of Librarians and Instructional Faculty (PhD diss., Montana State University, 1990).

58. W. Bede Mitchell \& Mary Reichel, "Publish or Perish: A Dilemma for Academic Librarians?" College \& Research Libraries 60, no. 3 (05, 1999): 232.

59. Shannon Cary, "Faculty Rank, Status, and Tenure for Librarians," College \& Research Libraries News 62, no. 5 (05, 2001): 510.

60. Association of College and Research Libraries, "Faculty Rank, Status, and Tenure for Librarians," "1999 academic library trends \& statistics,", ACRL, Chicago, 2000.

61. Janet Krompart \& Clara DiFelice, "A Review of Faculty Status Surveys, 1971-1984," Journal of Academic Librarianship 13, no. $1(03,1987): 17$.

62. Hill, "Wearing our Own Clothes: Librarians as Faculty."

63. McAnally, "Status of the University Librarian in the Academic Community."

64. University of Wyoming, "University Regulations 631: Regulations of the University Libraries," http://uwadmnweb.uwyo.edu/legal/ Uniregs/ur631.htm (accessed October 15, 2007).

65. ALA, Standards for Faculty Status for College and University Librarians, September 06, 2006.

66. University of California, UC Academic Policy Manual 360, Appointment and Promotion, Librarian Series, http://www.ucop. edu/acadadv/acadpers/apm/apm-360.pdf (accessed October 15, 2007).

67. University of Georgia Libraries Faculty Guidelines for Librarian/ Archivist Rank and Promotion, http://www.libs.uga.edu/staff/ facprom.html (accessed October 15, 2007).

68. ACRL, Faculty Rank, Status, and Tenure for Librarians. 